\title{
Evaluation Learning Program "You And Me" At The Kindergartens Built by PKBI In Central Java
}

\author{
Ode Yahyu Herliany Yusuf \\ STAI YPIQ BAUBAU \\ Islamic Preschool \\ Kota Baubau, Indonesia \\ ode.yahyu85@gmail.com
}

\begin{abstract}
This study aims to evaluate sex education programs called "You and Me." This study was conducted in three preschools namely Kindergarten Lab school UNNES, Taman Belia Kindergarten, and TK Post Anak Bangsa preschool with CIPP evaluation model (Context, Input, Process, Product). The study applied a quantitative descriptive approach. Research subjects included students, teachers, principals, and parents. The data was collected by observation and questionnaire. The results showed that there is the suitability of the program with the needs of the child and the parent's participation. Student motivation, teacher's pedagogic competency, teacher's professional competence, teacher's personality competency, teacher's social competence, alignment of the learning program guidebook as a reference, media completeness, and program funding indicate good outcome criteria. The process variable consists of learning planning, learning implementation, and learning assessment also shows good results which are in accordance with preschool process standards. The skills and knowledge of children are in accordance with the objectives of the program and the results are very good with a score of $100 \%$. The product variable consists of the understanding of educators in displaying and practicing learning obtained very good results with a score of $100 \%$. It can be concluded that the educator's understanding of learning makes the students have the skills and knowledge about the "You and Me" learning program so that this is in accordance with the objectives of the program.
\end{abstract}

Keywords-"You and Me" Learning Programs; Sex Education.

\section{INTRODUCTION}

Still very clearly remembered sexual abuse in children that occurred in kindergarten at JIS (Jakarta International School), and who perform acts of sexual abuse is cleaning services and two teachers. As well as according to the news on 6 SCTV coverage on 21/11/2015, the police arrested a (biological) father in Bolang Mongondow district (North Sulawesi) for raping his own underage child. The victim has been raped since July 2015 , the victim did not dare to against at all, because threatened with sharp objects (machetes). This case was revealed because the victim told his friend. There are still many other children who are also suspects who are the closest to the child themselves. Whether it's from neighbors, family, or biological parents, it can be seen how vulnerable a child is to sexual crime. This is because children do not understand the act of sexual abuse when they experience it, and children cannot do anything.
The recent increase in cases of child sexual violence (KSA) is no longer just threatening teenagers who are vulnerable to misinformation about sex. Sexual exploitation in underage children is also often the case with the closest people. In 2007 KSA done by the families of the victims themselves at $7.2 \%$ [1] and by the National Commission for Child Protection said that in 2016 the closest perpetrators reached $70 \%$ including fathers, relatives, neighbors, teacher, and friend of the victim. The remaining 30\% are unknown people.

Throughout the year 2015, there were around 35 victims of sexual violence cases that occurred in children in the city of Semarang (the data center of the Integrated Service Center "SERUNI" of Semarang City). Moreover, the importance of Sexuality Education for Early Childhood is not just because of the rampant cases of sexual violence, but that this sexuality education must be given throughout human life (Jembawan 8 , 2015: 39).

The increase in cases of violence is clear evidence of children's lack of knowledge about sex education that they should have obtained from their first year by their parents. But the public's perception of sex education which still considers taboo to be discussed with children is a reason that must be addressed together to equip children to fight the increasingly transparent flow of globalization in various matters including sexuality.

The following are some of the wrong sex education factors, quoted from Yousef Mardan's book (2014, p. 65-79), among others: 1) sexual stimulation in the family, 2) adjacent beds, 3 ) imitation of sexual behavior, 4 ) women's jewelry, 5) kissing and touching sexual organs, 6) family ignoring the supervision of information media, 7) friends having bad character.

The tendency of children to play with their genitals is not an early sexual manifestation but as a "fundamental physical pleasure" that greatly regulates the life of a child. Physical satisfaction can be obtained through suction, intestines, skin stimulation, masturbation, and fun for nakedness. Other considerations, sex education, was given before because the basic human character was formed in childhood, and psychoanalytic experts have proved good or not a good effect in the first years towards the growth of the child's basic character.

Incorrect education can affect the development of various forms of sexual deviation in the future. Sex education at an 
early age is activated to be able to rectify children's sexual understanding and behavior so that it can be more positive [2].

Researchers taking research in three centers were kindergartens namely TK Lab School in Sampangan area, TK Taman Belia in Tanah Putih area and Post PAUD Anak Bangsa in Pedurungan area. Semarang is the youngest city in implementing the "You and Me" program, However, its action in other cities in Indonesia that have implemented these programs since 6-7 years ago. The reason PKBI Central Java chose these 3 Kindergartens is that two of them are role mode schools in their respective districts such as the Unnes Kindergarten Lab School and Taman Belia Kindergarten, while the Pos PAUD Anak Bangsa is an area where sexual violence often occurs.

\section{LEARNING PROGRAM “YOU AND ME”}

The "You and Me" program is a life skill education program for reproductive health and sexuality targeting children aged 4-6 years. This program is important in the framework of the basic foundation for children to develop positive attitudes and life skills including those related to social relations, prevention of sexual violence, reproductive health and sexuality and building trust and communication with parents about early sexuality [3].

PKBI Central Java and Rutgers WPF Indonesia provided training in parenting activities and socialization to PAUD teachers about the Sexuality Education for Early Childhood program called the "You and Me" program. In facilitator training not only attended by PAUD teachers but also academics from universities in Semarang as well as psychologists. Before starting to implement this Sexuality Education program, schools that will implement inform sexuality education comprehensively to parents. So that parents can receive and then feel the benefits of this program. Knowledge about sexuality education was also measured using pre and post tests prepared by the team. The results of the pre and post-test will later be processed and will be used as material in advocacy and research that will be followed up by the facilitator "You and Me" from academics.

The purpose of the "You and Me" Program [3] generally helps lay the foundation for developing attitudes, knowledge, and skills that children need to adapt to their environment, including understanding sexuality and reproductive health for future growth and development. In particular, the "You and Me" Learning Program helps children to develop themselves as:

- Respect yourself and others.

- Understanding your own feelings and those of others, desires, opinions, and others.

- Can make appropriate decisions regarding sexuality, especially for the prevention of sexual violence.

Children's early education is from their parents, so parents must know sexual education. Reference [3] provides some information about what parents should know about sexual education:
- Habits of Children Holding Gender Children holding and feeling their genitals when they are 4-6 years old are natural because at that time the child is exploring and knowing him. This period is called the phallus/phalik period, which is when it touches and touches its own genitals.

- Prevention of Sexual Harassment: Safe and Non-Safe Touch for Children.

At this time parents need to provide understanding to children that their bodies are their own. Therefore the body must be cared for and protected from irresponsible people. In providing understanding to children, parents should also explain that in the body there are personal body parts such as breasts, vagina, penis, anus, buttocks, thighs, and others. Therefore not just anyone can touch or hold that part for obvious reasons, for example, the mother can hold the anus to clean after bowel movements, the doctor checks out the body parts that hurt. If there are people who want to touch not with the right reasons, then parents can teach children to say "no" [3].

Children can also be taught about safe touch and unsafe touch [3]:

- A safe touch is a touch that can make a child feel comfortable, not threatened such as for example holding / holding hands, putting together and others.

- An unsafe touch is a touch that is done repeatedly on certain body parts and touches that point to the body members that are personal.

Besides that children can also be taught to act if they feel threatened and uncomfortable with those touches. The things that can be done by children are [3]:

\section{A. Say "no" or reject in a reasonable tone.}

Children can be taught to say "I don't like it when my hair is pushed," "I don't like my body to be pushed," or "I don't like it when my chest is touched."

\section{B. Shout out.}

If the words above do not make the behavior (both children and adults) stop the treatment, parents can teach children, that if children feel threatened or uncomfortable with certain touches, children can shout by saying "I don't want to," " do not," not," etc.

\section{Run towards a crowd or people.}

Every child has a different attitude and character. There are children who are quiet, but some are not. If the child has a quiet nature and if the offender cannot stop the treatment even though the child has shouted, then the child can be taught to run towards a crowd of people or crowds. Do not occasionally run to a quiet place; this will aggravate the situation.

\section{Tells adults.}

After the child runs towards the crowd, the child can be taught to be able to tell other trusted adults 


\section{SEXUAL EDUCATION}

Reference[1] state that sex education is a conscious activity of families and communities to convey the marriage process according to religion and that has been applied by the community. The point is sex education must not conflict with religion. Whereas, [4] argues that sex education is the study of human body parts but still in religious rules.

Reference [5] said that: Sex education is essential for all young people in order to help prepare them for the responsibilities of adult life". Effective sexuality education can provide young people with information that is age-appropriate, culturally relevant and scientifically accurate. This includes structured opportunities for young people to explore their attitudes and values, and practice decision making and other life skills they must be able to make informed choices about their sexual lives [6].

Teaching correct sexual terms and familiarizing children with a matter-of-fact discussion of sexual development, etiquette, and values lay the groundwork for reporting exploitative behavior." Laying the foundation of an effective and easiest educational foundation if done early on in preschool. At this age, the development of children is very rapid. Because the findings in the field of neuroscience helped lead psychologists to the conclusion that early age (0-6 years) is a golden age.

Reference [7] explained that most experts believe that sex education for preschoolers is about knowledge of sexual physiology and the cultivation of healthy sexual psychology, education of sexual physiology knowledge that tells the origin of children's lives - children, scientific names of men and female genital organs, and gender differences in physiological structures and how to regulate good sexual health habits and protect their bodies; whereas healthy psychosexual cultivation is to help children form positive attitudes and good gender, eliminate sexual mysteries, prevent sexual depression and sexual crimes that occur, identify their own sex, learn their gender roles in accordance with social regulations and so on. And developing healthy sexual psychology must be emphasized, and knowledge of sexual physiology should be provided as simply as possible during sex education in children.

Reference [8] suggests topics that are appropriate for the age of children for sexuality education, namely:

- Good touch and a bad touch.

- Understanding body parts, the right name for anatomy, the basic stages of the growth process.

- The concept of infectious diseases / non-communicable diseases.

- Behavior that reduces the spread of infectious diseases (hand washing, not sharing eating utensils, using tissue).

- Accept their uniqueness and positive things for themselves and others.

- $\quad$ Recognize the risk of behavior (sharing body fluids) and prevention methods.
- Introducing unsafe objects (needles, broken glass, drug possession)

- Rejection skills (role-playing).

- Cleanliness

- Emotional development

Reference [9] parents are responsible for maintenance when children are born roles that are just starting out, and parents start new ways of living. But ironically, often parents have difficulties. Therefore they must cooperate with schools or parties close to the child's social environment in order to provide education that is in line with what is given at home. With education and habituation from the beginning to talk about sexuality, children will inevitably be more open in discussing sex issues with parents and teachers as the main source.

\section{VALUATION OF LEARNING PROGRAMS}

Reference [10] states that evaluation is a process that determines conditions, where a goal has been achieved. Whereas Indeed Norris said that "Argues that evaluation applies research methods to shed light on a problem of action; he suggests that evaluation can be viewed as an extension of research, because it shares its methodologies and methods, and because evaluators and researchers possess similar skills in conducting investigations. In many senses, the eight features outlined above embrace many elements of the scientific methods.

This definition explains directly the relationship of evaluation with the aim of an activity that measures the degree to which an event can be achieved. Actually, evaluation is also a process of understanding, giving meaning, gaining, and communicating information for the needs of decision makers.

The purpose of evaluation according to [11] "The basic purpose of the evaluation is to render judgments about the value of whatever is being evaluated. Many different uses may be made of those value judgments, as well shall discuss shortly, but in every instance the central purpose.

In the CIPP model evaluation serves four types of decisions: (1) planning decisions, which influence, selection of goals and objectives, (2) structuring decisions, which ascertain optimal strategies and procedural design for achieving the objectives that have been derived from planning decisions, (3) implementing decisions, which afford the means for carrying out and improving upon the execution of already selected design, methods, or strategies; (4) recycling decisions, which determine whether to continue, change, or terminate an or activity or even the program itself.

The CIPP evaluation model provides four types of decisions, namely (1) planning decisions that affect the choice of objectives in general and specifically, (2) structuring decisions that determine strategy and design optimal procedures in order to achieve the objectives determined by planning decisions, (3) recycling decisions that determine whether an activity or even a program will be continued, improved or stopped. 
The CIPP model is an evaluation model developed by [12] the CIPP evaluation model is viewed from its interests, namely “(1) Context evaluation as a means of servicing planning decisions, (2) input evaluations these structuring decisions, (3) process evaluations to guide implementing, dan (4) product evaluations to serve recycling decisions". The CIPP evaluation model contains three main things, namely describing, collecting, and presenting information that can be taken into consideration in making decisions and the accountability of the implementation of a program.

The following CIPP according to Stufflebeam are as follows:

- "...identify the strengths and weaknesses of some object...(1985:169)"

- "The main orientation of an input evaluation is to help prescribe a program by which to bring about needed changes...(1985:173).

- "... to provide feedback to managers and staff..., to provide guidance for modifying or explicating the plan as needed..., to assess periodically the extent to which program participants accept and are able to carry out their roles.

- "The purpose of product evaluation is a measure, interpret, and judge the attainment of a program."

TABLE I. AN INDICATOR OF EVALUATION CIPP

\begin{tabular}{|l|l|}
\hline \multicolumn{1}{|c|}{ Evaluation } & \multicolumn{1}{|c|}{ Content } \\
\hline Context & $\begin{array}{l}\text { Suitability of the "You and Me" learning program } \\
\text { with the basic needs of children. } \\
\text { Parental support }\end{array}$ \\
\hline Input & $\begin{array}{l}\text { Motivation of students } \\
\text { Educator } \\
\text { Media completeness } \\
\text { Suitability of the guidebook as a reference }\end{array}$ \\
\hline Process & $\begin{array}{l}\text { Planning } \\
\text { Implementation } \\
\text { Assessment }\end{array}$ \\
\hline Product & $\begin{array}{l}\text { The purpose of the "You and Me" learning } \\
\text { program can be achieved. } \\
\text { Understanding educators in displaying and } \\
\text { practicing learning }\end{array}$ \\
\hline
\end{tabular}

a. An indicator of Evaluation CIPP

\section{VALUATION METHOD}

The type of evaluation used is a type of program evaluation, namely an activity or activity designed to implement the policy and implemented for an unlimited time [13]. In line with the statement, [14] program evaluation is evaluative research, which is intended to find out the end of a policy program, which is knowing the end result of the policy, in order to determine recommendations on past policies, which in the final goal is to determine next policy. Here the researcher will determine whether the service or intervention has reached the stated goal.

This type of evaluation research is an evaluation using the CIPP model (context, input, process, and product), and the approach used is quantitative descriptive. This approach is used to obtain accurate information which in this case describes the implementation of the program "You and Me" in PKBI guided TK Central Java.

The location of the study took place in three kindergarten institutions in Semarang, Central including:

- TK Lab School UNNES

- TK Taman Belia

- $\quad$ TK Post PAUD

The study was conducted in the 2016-2017 school year, through three stages, namely:

- Pre-survey stage in October-November 2016

- The stage testing instrument and data retrieval in the year 2017.

- The stage of data analysis and final report writing.

The population here are schools that use the "You and Me" learning program, namely the TK Lab School UNNES, TK Taman Belia, dan TK Post Paud Anak Bangsa. Below are tables from Kindergarten that will be population:

TABLE II. POPULATION IN KINDERGARTENS

\begin{tabular}{|c|c|c|c|c|}
\hline \multirow{2}{*}{ School } & \multirow{2}{*}{ Teachers } & \multicolumn{2}{|c|}{ Students } & \multirow{2}{*}{ Parents } \\
\hline & & $T k A$ & $T k B$ & \\
\hline $\begin{array}{ll}\text { TK Lab School } \\
\text { UNNES }\end{array}$ & 2 & 15 & 13 & 28 \\
\hline TK Taman Belia Candi & 16 & & 35 & 35 \\
\hline $\begin{array}{l}\text { TK Post Paud Anak } \\
\text { Bangsa III }\end{array}$ & 2 & 19 & 19 & 38 \\
\hline Jumlah & 20 & 34 & 67 & 101 \\
\hline
\end{tabular}

The sampling technique used in this study is incidental sampling, which is a coincidence-based determination technique. It means that the sample taken by the chance to meet with the researcher can be used as a sample if it is deemed that people happen to be found it is suitable as a source of data [20]. Where each PAUD will be taken by 2 teachers who understand the "You and $\mathrm{Me}$ " learning program while the accompanying teacher does not become a sample, 6 TK B class students, while TK A is not sampled because TK B is longer in learning about this sexual education, and 2 parents, so the number of samples in this study were 30 people. According to the source and type of data collected, the techniques used for data collection in this study are observation, interviews, questionnaires, and documentation.

\section{RESULTS AND DISCUSSION}

In this section the researcher will explain the object of research and the researcher also finds facts when observing, there are three schools that are the object of research, i.e.:

\section{A. School Conditions}

\section{1) TK LAB UNNES}

Address on Jl. Menoreh Tengah sampangan area is one of the best schools in the city of Semarang. By being helped by one of the teachers responsible for the "You and Me" program, 
namely Sri Wiji Handayani, S.Pd. The 28 students were divided into 4 classes, namely sunflower, orchid, jasmine, and lotus.

At the time of field observation, researchers found many interesting things, from the school environment, from the teaching team, and the teaching and learning process in the classroom. Associated with the "You and Me" program, this program was held at the beginning of the semester, so the school only repeated it at the same time reminding children of previous learning. The packaged learning is very fun to make students feel they are playing, the teacher in question is very creative in terms of presenting teaching materials. Even with the same theme every week, the way the teacher presents and displays learning theories varies.

\section{TABLE III. THE ACTIVITIES TK PAUD LABSCHOOL UNNES}

\begin{tabular}{|c|c|c|c|}
\hline $\begin{array}{l}\text { Research } \\
\text { Schedule }\end{array}$ & Class & $\begin{array}{c}\text { The number of } \\
\text { students }\end{array}$ & Activities \\
\hline $4 / 4 / 2017$ & & - & \multirow[b]{5}{*}{ OBSERVATION } \\
\hline $10 / 4 / 2017$ & Orchid & 8 & \\
\hline $18 / 4 / 2017$ & Sun Flower & 7 & \\
\hline $25 / 4 / 2017$ & Jasmine & 6 & \\
\hline $26 / 4 / 2017$ & Lotus & 7 & \\
\hline
\end{tabular}

This school is a safe place for students. After school children are not left outside the gate before parents pick up or are transported by school vehicles. The teacher accompanied his students, and the security guards appeared to supervise other students as well. If the student arrives at the time of departure and no one has picked up, the child is left to play in the classroom or outside the classroom.

\section{1) TK Post PAUD Anak Bangsa III}

This school is a children's playgroup located on Jalan Kinibalu Timur, Tandang, Tembalang District, Semarang City. This school has a settlement area, with self-help from the local community and a little help from the government so that the school can run smoothly until now. This school occupies a tennis gymnasium, with 1 room large enough to accommodate all students. The number of students is around 35 children, and about 5 teachers who teach and help are offered. Sri Indarwati is a teacher and headmaster and responsible for learning you and me. The research schedule conducted in this school is as follows:

\section{TABLE IV. ACTIVITIES IN AT TK POST PAUD ANAK BANGSA III}

\begin{tabular}{|l|l|l|}
\hline Research Schedule & Class & \multirow{2}{*}{ The number of students } \\
\hline $3-4-2017$ & 27 & \\
\cline { 1 - 2 } $3-4-2017$ & 25 & \multirow{3}{*}{ OBSERVATION } \\
\hline $17-4-2017$ & 19 \\
\hline $27-4-2017$ & 22 & \\
\hline $4-5-2017$ & 31 & \\
\hline
\end{tabular}

There are some disadvantages that occur in this school, such as 1) when learning parents follow and accompany their children, 2) all children are made into one class together, 3) the learning process is only for the teacher without any feedback from the students. This is because the number of children is very large and there are parents who follow the learning process so that children are more focused on parents. Although there are shortcomings, the school teachers are very creative. Every time you change the theme of learning, the way to convey it is different. Highly communicative teachers make the students very enthusiastic and enthusiastic about participating in learning. It takes hard work in looking for children's attention so they can focus.

\section{2) TK Taman Belia Candi}

The location of this school is on Jalan Singotoro, Candisari, Semarang City, Central Java. This school is one of the best schools in the city of Semarang. This school divides the class into several groups. At the time of observation, researchers only focused on the kindergarten class A and TK B. The ones responsible for the "You and $\mathrm{Me}$ " learning program were all teachers. According to the principal, Chitra Pratiwi, S.Pd, learning is carried out by all teachers, so in any class, the child is attending, the teacher can provide an explanation of sex education.

TABLE V. ACTIVITIES IN TK TAMAN BELIA CANDI

\begin{tabular}{|l|l|l|l|}
\hline Research Schedule & Class & $\begin{array}{c}\text { The number of } \\
\text { students }\end{array}$ & Activities \\
\hline $5 / 4 / 2017$ & & - & \multirow{3}{*}{ Observasi } \\
\hline $6 / 4 / 2017$ & Pink & 9 & \\
\hline $11 / 4 / 2017$ & Ungu & 11 & \\
\hline $25 / 4 / 2017$ & Orange & 11 & \\
\hline $26 / 4 / 2017$ & Green & 8 & \\
\hline $2 / 5 / 2017$ & $\begin{array}{l}\text { Orange- } \\
\text { Pink }\end{array}$ & 20 & \\
\hline
\end{tabular}

TK Taman Belia Candi is divided into 8 centers, namely neuro kinesthetic movement, cooking, faith and taqwa, art, preparation, beam, role-playing, and the last is natural material and science. Different from others, this school does not specialize in "You and Me" learning as its own theme. However, it is combined with scheduled centers. Teachers who are very professional and creative make the teaching and learning process very interesting.

\section{B. CIPP Evaluations}

Context evaluation is a description and specification of the program environment, needs that have not been met, population characteristics and samples of individuals served as well as program objectives. Context evaluation helps plan decisions, determine the needs to be achieved by the program and formulate program objectives. The following is an analysis of context evaluation based on data on the research that has been done.

In this chapter the researcher will explain the object of research, here researchers conduct research in three schools. First is the TK LAB UNNES, TK Taman Belia, dan TK Post Paud Anak Bangsa. The results of the CIPP analysis are as follows: 


\section{1) Context}

To reveal data obtained from teachers and parents about the suitability of the "You and Me" learning program with the basic needs of children using questionnaires and described in table form. The guideline questionnaire sheet consists of 7 questions. And at the data of participation of parents using a questionnaire and the analysis results obtained are as follows:

TABLE VI. CONTEXT TEACHERS AND PARENTS

\begin{tabular}{|c|c|c|c|}
\hline & $\begin{array}{c}\text { Teacher - Suitability } \\
\text { of the "You and Me" } \\
\text { Learning Program } \\
\text { with Children's Basic } \\
\text { Needs }\end{array}$ & $\begin{array}{c}\text { Parents - } \\
\text { Suitability of } \\
\text { Learning Programs } \\
\text { with Children's } \\
\text { Basic Needs }\end{array}$ & $\begin{array}{c}\text { Parents - } \\
\text { Parent } \\
\text { Participation }\end{array}$ \\
\hline Mean & 3.4286 & 3.5114 & 3.1676 \\
\hline Min & 2.86 & 2.43 & 2.13 \\
\hline Max & 4.00 & 4.00 & 4.00 \\
\hline
\end{tabular}

From the table above, the suitability of the "You and Me" learning program with the basic needs of children can be obtained from the teacher. Namely, the average obtained is 3.4286 , the lowest value is 2.86 , the highest value is 4.00 . while the data obtained from parents is an average of 3.5114, the lowest value is 2.43 , the highest value is 4.00 , and the data obtained from parents about parental participation is an average of 3.1676, the lowest value is 2.13 , and the highest value 4.00. It can be seen in the diagram below:

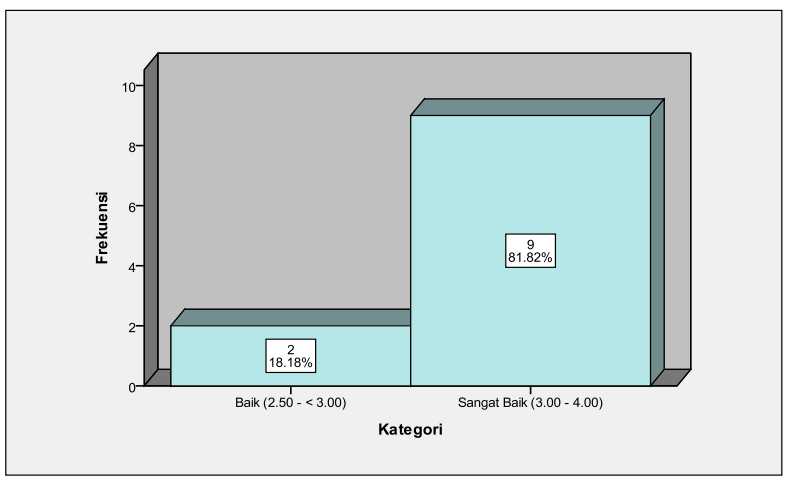

Fig. 1. Context Evaluation of Suitability of the "You and Me" Learning Program with Children's Basic Needs

During the study, information was obtained about the suitability of the program with these children's needs obtained from questionnaires given to teachers and parents. The results obtained in the questionnaire stated that the learning program

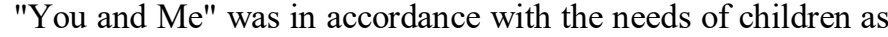
much as $18.2 \%$ with good / appropriate categories, and $81.82 \%$ with very good / very appropriate categories where children should be given an understanding of sex education early and in accordance with its development. Context data related to the compatibility of the "You and Me" learning program with children's basic needs were also obtained from parents. The data is displayed as follows.

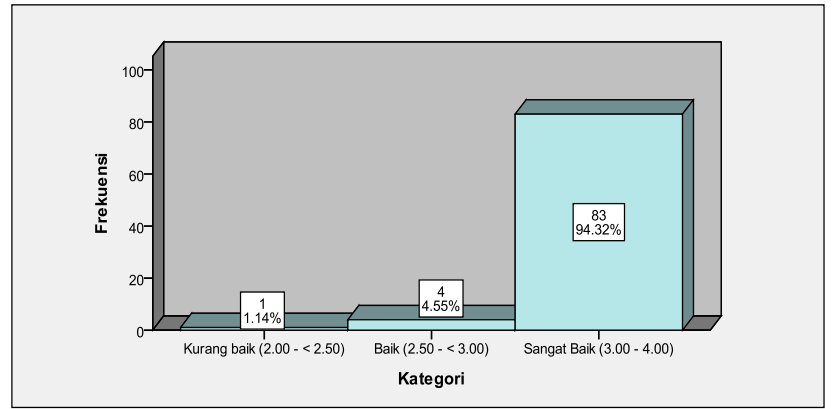

Fig. 2. Context Evaluation of Suitability of Learning Programs with Children's Basic Needs

If seen from the table and diagram above there are slight differences in the results obtained for parents, for the level of suitability of the program with the needs of children obtained poor results $1.1 \%$ stated poor (not appropriate), $4.5 \%$ stated good (appropriate), and 94.3\% stated very good (very suitable). But the results of the average obtained that this learning program is in accordance with the basic needs of children. This is the same as the results obtained from the teacher.

\section{2) Input}

Evaluation of input helps to regulate decisions, determine available resources, what alternatives are taken, plans and strategies to achieve goals. Evaluation helps to regulate decision, determine the available resources, what alternatives will be taken, what plans and strategies to achieve needs, and how work procedures to achieve them.

The evaluation of input consists of student motivation, teacher pedagogical competence, teacher professional competence, teacher personal competence, teacher social competence, suitability of the learning program guidebook as a reference, media completeness, and program funding. Based on information from the principal and students, the results obtained in the input evaluation are as follows:

TABLE VII. INPUT EVALUATION

\begin{tabular}{|c|l|l|l|l|l|}
\hline & $\begin{array}{c}\text { Conformity of } \\
\text { the Guidebook }\end{array}$ & $\begin{array}{c}\text { Completeness of } \\
\text { Learning Media }\end{array}$ & \multicolumn{1}{|c|}{ Student Motivation } & $\begin{array}{c}\text { Principal - Program } \\
\text { Financing }\end{array}$ & $\begin{array}{c}\text { Parents - Program } \\
\text { Financing }\end{array}$ \\
\hline Mean & 3.4091 & 3.3939 & 3.3273 & 2.3250 & 2.66 \\
\hline Min & 3.00 & 3.00 & 2.20 & 1.50 & 1 \\
\hline Max & 4.00 & 4.00 & 4.00 & 2.50 & 4 \\
\hline
\end{tabular}

Based on the results of the data during the study, the average results were 2.66 , median 3.00 , mode 3 , deviation standard 8.56 , low score 1 , highest score 4 . 
TABLE VIII. INPUT PRINCIPALS -TEACHER COMPETENCE

\begin{tabular}{|l|l|l|l|l|}
\hline & \multicolumn{1}{|c|}{ Pedagogic } & \multicolumn{1}{c|}{ Personality } & \multicolumn{1}{c|}{ Professional } & \multicolumn{1}{c|}{ Social } \\
\hline Mean & 3.1400 & 3.3941 & 3.2500 & 3.1400 \\
\hline Min & 2.70 & 3.00 & 2.75 & 3.00 \\
\hline Max & 4.00 & 4.00 & 4.00 & 4.00 \\
\hline Sum & 31.40 & 33.94 & 32.50 & 31.40 \\
\hline
\end{tabular}

\section{3) The motivation of students during learning}

Motivation is a concept in many learning theories. This motivation is strongly associated with encouragement, attention, anxiety, and reinforcement feedback. This is in accordance with the International Journal of Humanities and Social Sciences and Education (IJHSSE) that for children to succeed, they may need more resources such as the internet, journals, books, and more, but most importantly they need parental support.

To uncover data from students about student motivation while the following learning using questionnaires. Questionnaire for students consists of 1 aspect consisting of 6 questions. Based on the results of the data during the study obtained an average yield of 3.3273, a low score of 2.20 , and the highest score of 4.00 . For more details, see the following diagram:

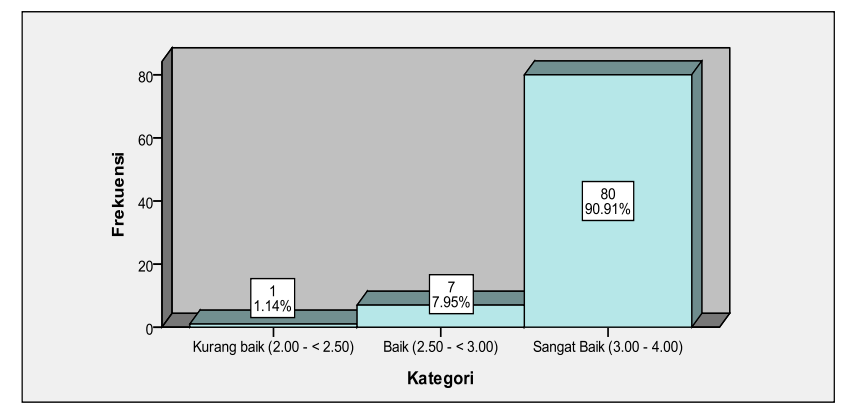

Fig. 3. Motivation of students

Based on the results of the program's evaluation of students' motivation in participating in learning, the percentage was obtained with a score of $90.91 \%$ with a very good category. To motivate students, teachers must have/master basic competencies - a set of knowledge, skills, and behaviors that must be owned internalized and mastered by the teacher in carrying out professional duties.

\section{4) Pedagogical Competence}

According to the 2013 curriculum that early childhood educators must have pedagogical competence. The competence of a teacher is that the teacher understands the characteristics of students from the physical, moral, social, cultural, and emotional aspects. Teachers must also be able to understand learning materials, can develop learning guidelines, and select media that are of interest to children.

To reveal data from the principal about pedagogical competence using a questionnaire. Questionnaire for students consists of 10 questions. Based on the results of the data, the researchers obtained an average yield of 3.1400, a low score of
2.70, and a high score of 4.00. For more details, see the following diagram:

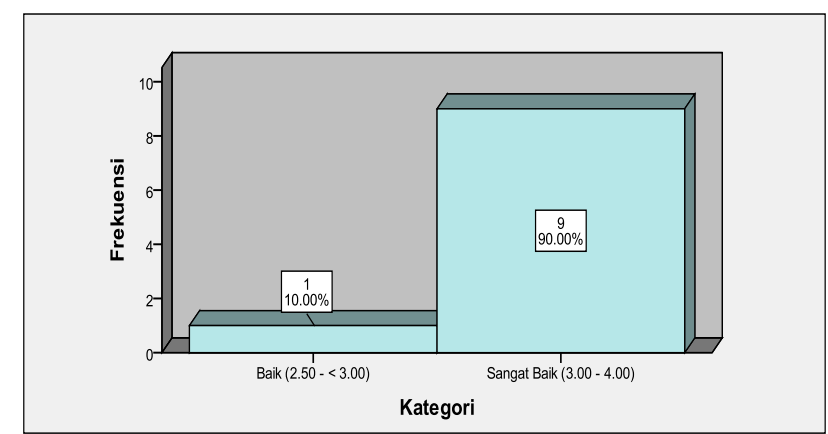

Fig. 4. Diagram of Pedagogical Competence

Based on the results in the diagram above, it was found that the competence in the teacher obtained a percentage with a score of $90.91 \%$ with a very good category. This is in accordance with the 2013 curriculum that early childhood educators must have pedagogical competence. The competence of a teacher is that the teacher understands the characteristics of students from the physical, moral, social, cultural, and emotional aspects. Teachers must also be able to understand learning materials, can develop learning guidelines, and select media that are of interest to children.

\section{5) Personality Competence}

Personality competency is the nature or character of the educator which includes a steady, stable, mature, wise and wise, authoritative, noble accent, an example of students and society, developing themselves and evaluating their own performance.

To reveal data from the principal about the competencies of the personality of the teacher using a questionnaire. Questionnaire for headmaster consists of 16 questions. Based on the results of the data during the study obtained an average yield of 3.3941, a low score of 3.00, and a high score of 4.00. For more details, see the following diagram:

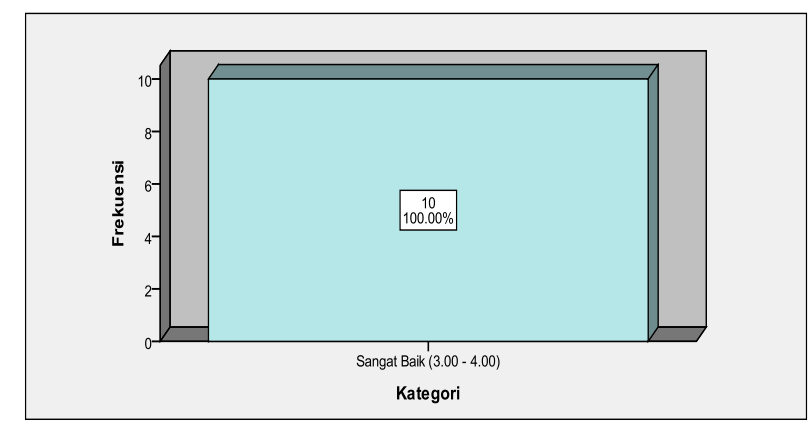

Fig. 5. Diagram of Personality Competence

This is in accordance with the 2013 curriculum that an educator must have personality competencies such as being able to communicate effectively, empathically, politely with students. A teacher must act in accordance with the norms, religion, law, and culture in Indonesia. Educators must also display good personality attitudes, dignity, responsibility, 
applying the teacher's code of ethics, and showing selfconfidence.

\section{6) Professional Competence}

Professional competence, namely the ability to master the subject matter widely and deeply. A professional teacher masters extensive knowledge, especially learning material that will be given to students and has the ability to develop learning programs and implement them. To reveal data from the principal about professional competence the teacher uses a questionnaire. Questionnaire for the principal consists of 10 questions. Based on the results of the data during the study obtained an average yield of 3.2500, a low score of 2.75 , the highest score of 4.00 . For more details, see the following diagram:

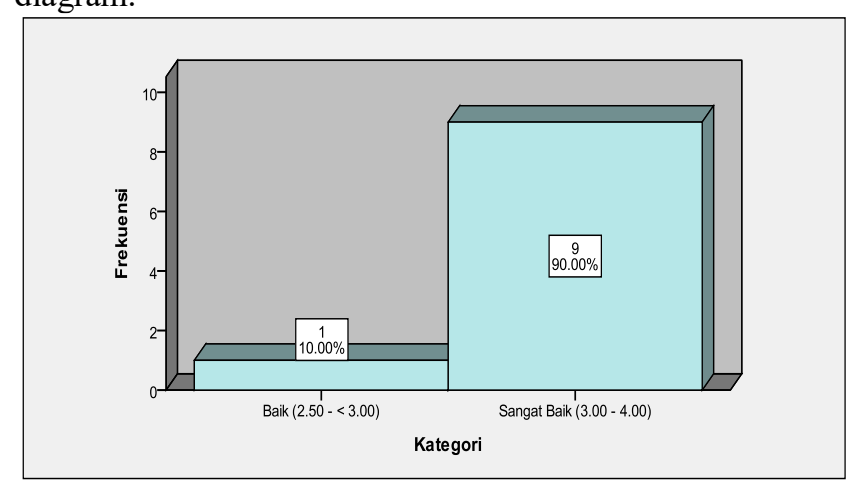

Fig. 6. Diagram Professional Competence

Based on the results in the diagram above, it was found that professional competence in the teacher obtained a percentage with a score of $90 \%$ with a very good category. according to the principal, that the teachers master the learning material, are able to develop learning materials, use the right method according to the development of students, are able to use learning media so that it makes it easier for students to understand the material provided by the teacher.

\section{7) Social Competence}

Gulnara I. Salyakhova and Roza A. Valeeva (2015:187) said social competence that the development of personality, his intellectual, emotional, volitional personal qualities as well as purposefulness, responsibility, humanity, tolerance, citizenship, and others. To reveal data from the principal about the social competence of the teacher, the researcher used a questionnaire. Questionnaire for the principal consists of 5 questions. Based on the results of the data during the study obtained an average yield of 3.1400, a low score of 3.00, and the highest score of 4.00. For more details, see the following diagram:

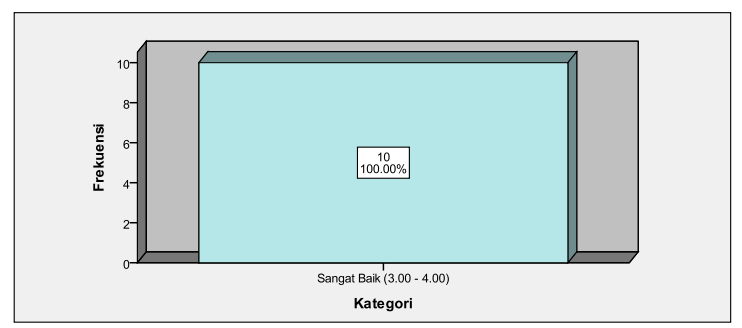

Fig. 7. Diagram Social Competence
Based on the results in the diagram above, it was found that social competence in the teacher obtained a percentage with a score of $100 \%$ with a very good category according to the principal's data that teachers in the school are able to communicate with students, fellow teachers, parents, and the community. This is in accordance with the National Education Standards, article 28 paragraph 3 , point $\mathrm{d}$, that what is meant by social competence is the ability of the teacher as part of the community to communicate and interact effectively with students, fellow educators, education personnel, parents / guardians of students, and the surrounding community.

8) Teacher Input - Suitability of the Guidebook

To uncover data from students about student motivation while the following learning using questionnaires. Questionnaire for students consists of 1 aspect consisting of 5 questions. Based on the results of the data during the study obtained an average yield of 3.4091, a low score of 3.00, and a high score of 4.00 . For more details, see the following diagram:

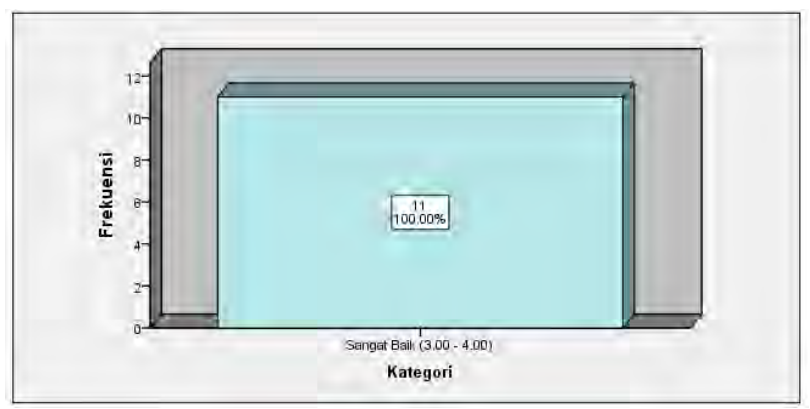

Fig. 8. Diagram Teacher Input - Suitability of the Guidebook

Based on the results in the diagram above, it was found that the suitability of the program manual as a reference obtained a percentage with a score of $100 \%$ with a very good category. This is in accordance with the law in the regulation of the national education minister, the government regulation article 1 number 4 that the educator's guidebook is a book that contains principles, procedures, descriptions of basic material, and learning models for use by educators. And also article 6 of the number that the textbook is used as a mandatory reference by educators and students in the learning process.

\section{9) Teacher Input - Completeness of Learning Media}

Ahsan Akhtar Naz and Rafaqat Ali Akbar (p.36) that Media is a means to transmit or convey messages and perspectives on teaching and learning that provide content to students, to achieve effective teaching. Learning media plays an important role in student education, so it is very supportive of the teaching and learning process of teachers and students in the class.

To reveal data from students about the completeness of learning media using a questionnaire. Questionnaire for students consists of 1 aspect consisting of 3 questions. Based on the results of the data during the study obtained an average yield of 3.3939, a low score of 3.00, and the highest score of 4.00. For more details, see the following diagram: 


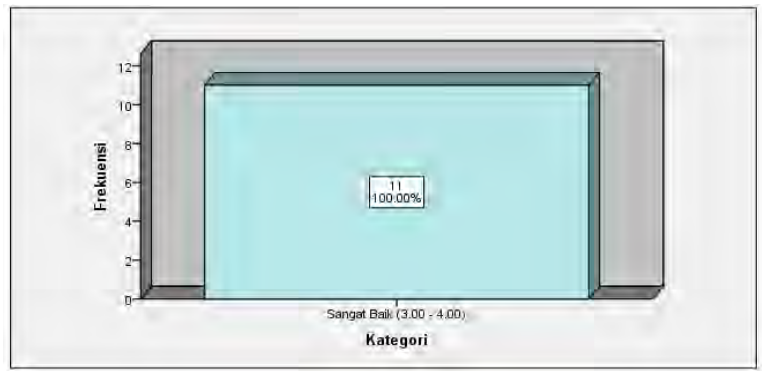

Fig. 9. Completeness of Learning Media

Based on the results in the diagram above, it was found that the completeness of learning media obtained a percentage with a score of $100 \%$ with a very good category. This is because the learning guidebooks for teachers and parents are in good condition and the condition of the books and props are in complete and good condition.

To reveal data from the principal about financing the program using a questionnaire. Questionnaire for the principal consists of 4 questions. Based on the results of the data during the study obtained an average yield of 2.3250 , a low score of 1.50 , and the highest score of 2.50 . For more details, see the following diagram:

10) Program Financing According to the Principal

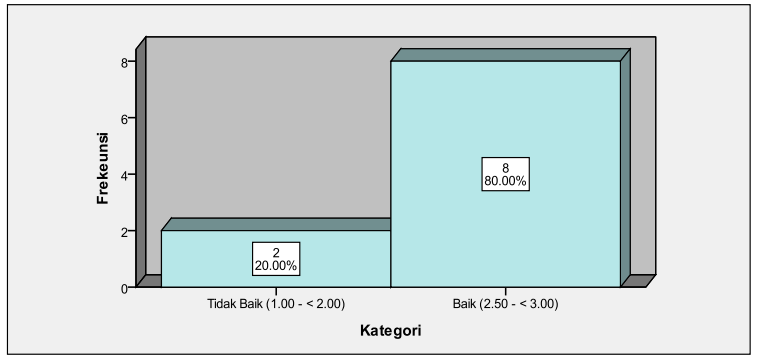

Fig. 10. Diagram of Financing from the headmaster

Based on the results of the diagram above, it was found that $80 \%$ of program funding was from the school, based on reports from the principle that the program was funded more by the school itself. The average school that finances the program is because from the parent side, including the poor and some parents think that it is the responsibility of the school and the government.

\section{1) Program Financing According to Parents}

To reveal data from parents of students about funding on the program using a questionnaire. Questionnaire for parents consists of 1 question. Can be seen in the table below.

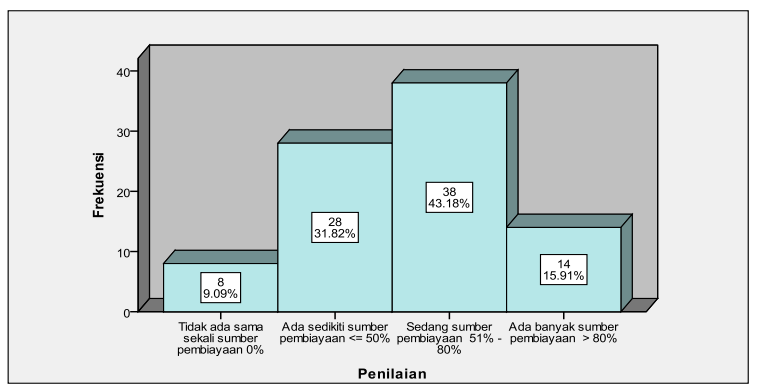

Fig. 11. Diagram of Financing from parents

Based on the results in the diagram above, it was found that the competence of teachers was obtained by percentage with a score of $14 \%$ and they participated in financing the program. So it can be concluded that the involvement of active parents in school activities such as helping their children in helping with homework can improve children's academic performance and in terms of financing.

\section{2) Process}

The purpose of process evaluation is to provide feedback to program makers and implementers, provide guidance to modify or explain in full planning if needed, and assess the level of mastery of the program and the completion of their tasks at a certain time. In this study, process evaluation consists of:

TABLE IX. LEARNING PROCESS

\begin{tabular}{|l|l|l|l|}
\hline & \multicolumn{1}{|c|}{ Preparation } & \multicolumn{1}{|c|}{ Implementation } & \multicolumn{1}{c|}{ Assessment } \\
\hline Mean & 3.6606 & 3.5804 & 3.1705 \\
\hline Min & 2.93 & 3.00 & 3.00 \\
\hline Max & 4.00 & 4.00 & 4.00 \\
\hline
\end{tabular}

\section{Learning Preparation}

To reveal data from the teacher about learning preparation using a questionnaire. Questionnaire for teacher consists of 15 questions. Based on the results of the data during the study obtained an average yield of 3,6606, a low score of 2.93, and a high score of 4.00 . For more details, see the following diagram:

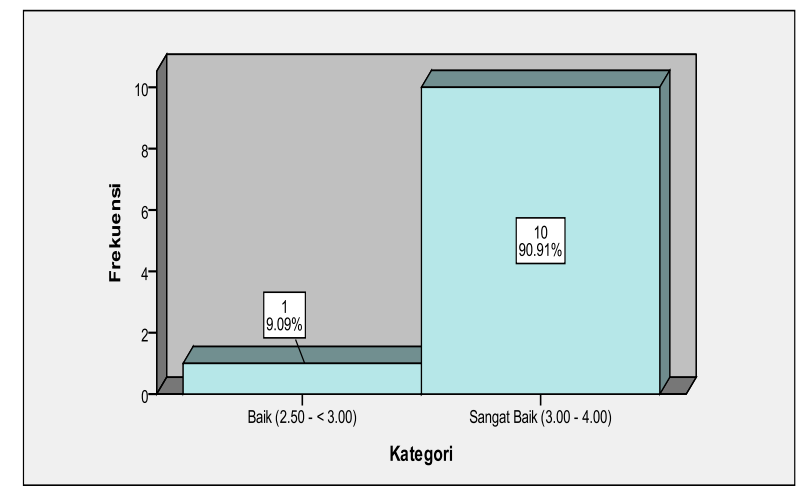

Fig. 12. Diagram of Learning Preparation 
Based on the above diagram, it was found that learning planning had a score of $90.91 \%$ with a very good category. this is because before the teacher has implemented everything as preparing lesson plans, media, and learning resources, learning assessment tools, and learning scenarios. It can be concluded that the planning process must be in accordance with the standards of the PAUD process, among others, making annual program, semester programs, weekly activity plan, or RPPM (plan daily activities for implementing weekly learning, RKH) or RPPH (plan for implementing daily learning).

\section{1) Implementation of Learning}

To reveal data from the teacher about the implementation of learning using a questionnaire. Questionnaire for teacher consists of 13 questions. Based on the results of the data during the study obtained an average yield of 3.5804, a low score of 3.00 , and a high score of 4.00 . For more details, see the following diagram:

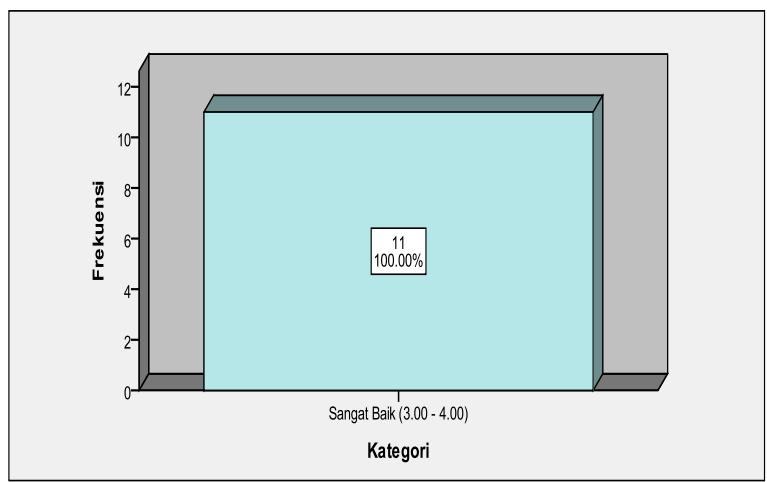

Fig. 13. Diagram of Implementation of Learning

Based on the results in the diagram above, it was found that the implementation of learning obtained a percentage with a score of $100 \%$ with a very good category. This is because the teacher follows according to what has been compiled in the RPP including the introduction, core, and closing activities.

2) Assessment of Learning Outcomes

To reveal data from the teacher about the implementation of learning using a questionnaire. Questionnaire for teacher consists of 13 questions. Based on the results of the data during the study obtained an average yield of 3.1705, a low score of 3.00 , and the highest score of 4.00. For more details, see the following diagram:

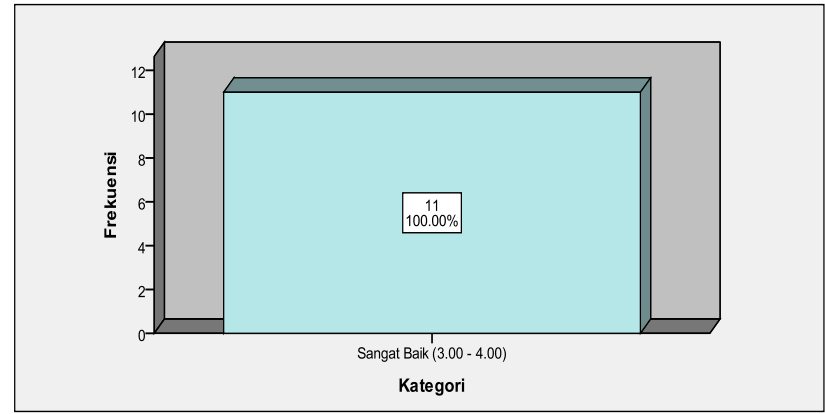

Fig. 14. Diagram of assessment

Based on the results in the diagram above it was found that the assessment of learning obtained a percentage with a score of $100 \%$ with a very good category. Teachers assess students not only from formal tests but from all aspects of development

\section{3) Product}

Product evaluation is to measure, interpret, and assess the results of achieving a program. Assessment of results is an assessment carried out in measuring the success of a program that has been determined.

TABlE X. Product Evaluation Results

\begin{tabular}{|l|l|l|}
\hline & \multicolumn{1}{|c|}{ Students } & \multicolumn{1}{c|}{ Teachers } \\
\hline Mean & 3.4470 & 3.9835 \\
\hline Minimum & 3.00 & 3.82 \\
\hline Maximum & 4.00 & 4.00 \\
\hline
\end{tabular}

4) Children's Achievement and Knowledge Are In Accordance with the Program Objectives

To reveal data from the teacher about the skills and knowledge of the child is in accordance with the objectives of the program using the questionnaire. Questionnaire for teacher consists of 9 questions. Based on the results of the data during the study obtained an average yield of 3.4470, a low score of 3.00 , and a high score of 4.00 . For more details, see the following diagram:

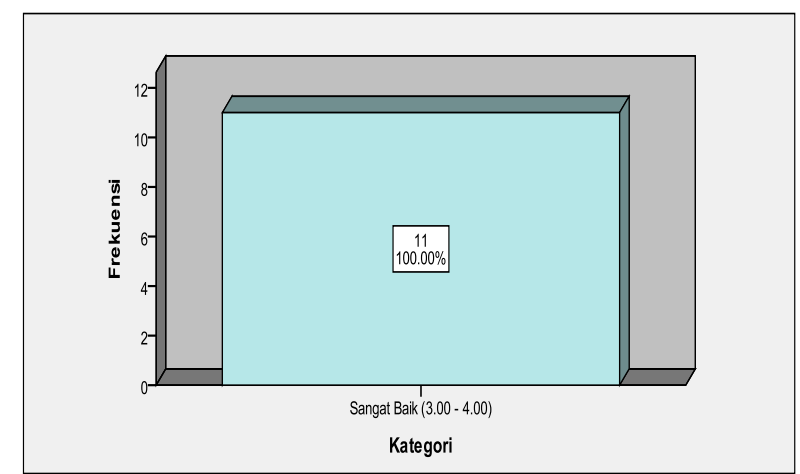

Fig. 15. Diagram of Children's Achievement and Knowledge

Based on the results in the diagram above it was found that the product results in students obtained a percentage with a score of $100 \%$ with a very good category. The product is said to be successful because it is in accordance with the program objectives. 
5) Understanding educators in displaying and practicing learning "You and Me."

Observations carried out by researchers in order to get the real data at the time of the research in the field, in addition to the data obtained from the questionnaire. The researcher observed educators in displaying and practicing learning "You and Me."

To uncover data from students about their skills and knowledge in accordance with the objectives of the program using an observation sheet consisting of 11 items of statements. Based on the results of the data during the study obtained an average yield of 3.9835, a low score of 3.82, and a high score of 4.00. Can be seen in the table below.

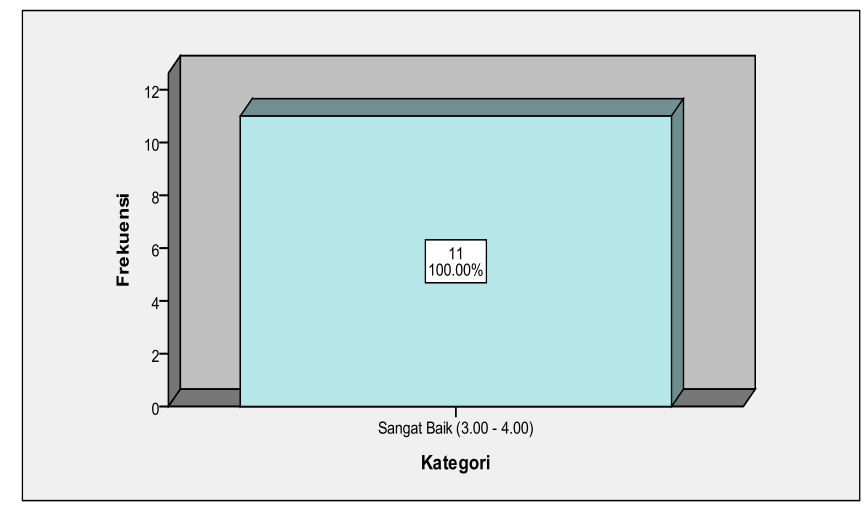

Fig 16. Diagram of Understanding of educators

Based on the results in the diagram above, it was found that the understanding of educators in displaying and practicing learning "You and Me" obtained a percentage with a score of $100 \%$ with a very good category. This is because the teacher has professional competencies that are in accordance with the 2013 curriculum that the teacher is able to develop learning material, using the right method according to the development of students, able to use learning media so that it makes it easier for students to understand the material provided by the teacher.

\section{CONCLUSION}

Based on the results of the analysis of the research and discussion presented in the previous chapter, there are several that can be concluded that relating to the evaluation of "You and $\mathrm{Me}$ " learning in PKBI Central Java-assisted kindergarten are as follows:

\section{A. Context Evaluation}

\section{Context evaluation consists of 2 components:}

- In the program suitability component according to the needs of children according to educators included in the category vary in accordance with the acquisition of results as much as $81.8 \%$, while the parents are also included in the category vary in accordance with the results obtained at $94.3 \%$. High curiosity makes them curious about these differences so that the existence of this program can meet the needs of children.
- In the component of parental participation, the results are $78.4 \%$, this includes the appropriate category. They enthusiastically participated and collaborated in giving opinions in the interests of students and schools.

\section{B. Input Evaluation}

Input evaluation consists of 8 components:

- Observational research on student motivation showed very poor results with a score of $90.9 \%$. In other words, the motivation of these students during the learning program was very interested and interested. In each process, students always show great interest and curiosity.

- The information obtained from the principal at the time of the research in the field regarding the pedagogical competence of the teacher was very good with a score of $90.91 \%$. Pedagogic competence is in accordance with the 2013 curriculum that a teacher must have pedagogical competence in teaching.

- Information obtained from the principal at the time of the research in the field regarding the professional competence of the teacher obtained very good results with a score of $90.91 \%$. This is in accordance with the 2013 curriculum that teachers must have professional competencies to understand and provide stimulation to learning.

- Information obtained from the principal at the time of the research in the field regarding teacher personality competencies obtained excellent results with a score of $90.91 \%$. This is in accordance with the 2013 curriculum that an educator must have personality competencies such as being able to communicate effectively, empathically, politely with students

- The information obtained from the principal at the time of the research in the field regarding the teacher's social competence obtained excellent results with a score of $100 \%$. This is in accordance with the National Education Standards, article 28 paragraph 3, point d, that what is meant by social competence is the ability of teachers as part of the community to communicate and interact effectively with students, fellow educators, education staff, parents/guardians of students, and the surrounding community.

- Completeness of the learning program guidebook as a reference has been very good with a score of $100 \%$. This is in accordance with the law in the regulation of the national education minister, the government regulation article 1 number 4 that the education guidebook is a book that contains principles, procedures, descriptions of basic material, and learning models for use by educators

- On the completeness of learning media obtained very good results with a score of $100 \%$, this is based on observation at the time of research that special learning media for the program was complete and in good condition. 
- The information obtained from the principal at the time of the research in the field regarding program funding shows that $80 \%$ of those who finance the program are from the school. Whereas, the results obtained from parents regarding program funding obtained a $14 \%$ yield where only a few of the parents have their own initiatives to assist in financing the program.

\section{Process Evaluation}

Process evaluation consists of 3 components:

- Learning Preparation during the research obtained very good results with a score of $90.0 \%$. This is in accordance with the standards of the PAUD process, among others, the making of annual program, promissory notes (semester program), RKM (weekly activity plan), or RPPM (weekly learning implementation plan), RKH (daily activity plan) or RPPH (plan implementation of daily learning). It can be concluded that in the implementation of learning the teacher really prepares all the needs and needs before entering the learning process.

- The implementation of learning during the study found very good results with a score of $100 \%$. This is because the teacher follows according to what has been compiled in the RPP including the introduction, core, and closing activities.

- Learning Assessment is very good with a score of $100 \%$. This is the arena where the teacher has followed Permendiknas No. 58 of 2009 that assessments can be carried out through observation, assignments, performance, recording anecdotes, conversations/dialogues, parental reports, and documentation of children's work or portfolios and children's profile descriptions.

\section{Product Evaluation.}

The skills and knowledge of children are in accordance with the objectives of the program and the results are very good with a score of $100 \%$. Whereas in the understanding of educators in displaying and practicing learning obtained very good results with a score of $100 \%$. It can be concluded that the educator's understanding of learning makes the students have the skills and knowledge about the "You and Me" learning program so that this is in accordance with the objectives of the program.

\section{REFERENCES}

[1] I. Paramstri and M. A. Priyanto, "Early Prevention Toward Sexual Abuse on Children," Jurnal Psikologi, Vol. 37, no.1, pp. 1-12, June 2010 .

[2] A. Zahrulianingdyah, Reproductive Health Education Model in Early Childhood through Education Film" Damar Wulan". Journal of Education and Practice, vol. 6, no.19, pp.184-189, 2015.

[3] World Population Foundation, Pedoman Pembelajaran "Aku dan Kamu" (Seri Buku Kecakapan Hidup Sosial Untuk Anak Usia Dini 4-6 Tahun). PKBI :World Population Foundation, 2008.
[4] M. Yousuf, Pendidikan Seks Usia Dini Bagi Anak Muslim. Jakarta: Zahra Publishing House, 2014.

[5] J. Lawrence, A. Kanabus and D. Regis, A Survey of Sex Education in Secondary Schools.British: Aids Education \& Research Trust, 2000.

[6] UNESCO, "International Technical Guidance on Sexuality Education (An evidence-informed approach for schools, teachers and health educators)", 2009.

[7] C. Zhina and W.Dingchu, "A Review of Sex Education for Preschool Children in Mainland China from 1992 to 2012," International Review of Social Sciences and Humanities, vol. 5, No. 2, pp. 12-18, 2013.

[8] M. A. T. V. Brad, Age-Appropriate Sexuality Education Topic Guidelines. USA: Oregon Department of Education, 2012.

[9] World Population Foundation, Pedoman Pembelajaran "Aku dan Kamu" (Seri Buku Kecakapan Hidup Sosial Untuk Anak Usia Dini 4-6 Tahun). PKBI:World Population Foundation, 2008.

[10] Sukardi, Evaluasi Pendidikan: Prinsip dan Operaionalnya. Jakarta: BumiAksara, 2011.

[11] B. R. Worthen, J. R. Sanders and J. L. Fitzpatrick, Program Evaluation: Alternative Approaches and Practical Guidelines.3rd eds. Boston: Allyn \& Bacon, 2004

[12] Stufflebean and Shinkfield, Systematic Evaluation. Boston: KluwerNijhoff Publishing, 1985.

[13] Wirawan, Evaluasi Teori Model Standar Aplikasi dan Profesi, Contoh Aplikasi Evaluasi Program: Pengembangan Sumber Daya ManusiaProgram Nasional Pemberdayaan Masyarakat (PNPM) Mandiri Pedesaan, Kurikulum, Perpustakaan, dan Buku Tes. Jakarta: Raja Grafindo Persada, 2011.

[14] Sugiyono, Metode Penelitian Pendidikan Pendekatan Kuantitatif Kualitatif, dan R\&D. Bandung: Alfabeta, 2013.

[15] A. Suharsini, Dasar-Dasar Evaluasi Pendidikan. Jakarta: Bumi Aksara, 2006 